\title{
Use of data assimilation techniques to analyze the significance of ectoproteolytic activity measurements performed with the model substrate MCA-Leu
}

\author{
François Lamy, Micheline Bianchi*, France Van Wambeke, Richard Sempéré, \\ Vincent Talbot
}

Microbiologie Marine, CNRS-INSU UPR 223, Université de la Méditerranée, Campus de Luminy Case 907. F-13288 Marseille Cedex 9, France

\begin{abstract}
Using data assimilation techniques, we tested coherency between different data sets of parameters measured during a biodegradation experiment performed on natural seawater. Parameters were dissolved organic carbon (DOC), dissolved free amino acids (DFAA), bacterial biomass and ectoproteolytic activity measured with the fluorogenic substrate L-leucine-4-methyl-7-coumarinylamide (MCA-Leu). The model, which considers dissolved organic matter as 3 polymeric pools (Mh1 very labile, Mh2 semi-labile and Mh3 refractory), was used to investigate consistency in the use of MCALeu to trace protein hydrolysis. Three assimilations were performed: (1) the first assimilation was on the set of data excluding the ectoproteolytic activity, $(2)$ in the second assimilation, data from the MCA-Leu technique were compared to the hydrolysis rate of the labile pool of proteins (Mh1) given by the model. and (3) the third assimilation was performed assuming that the measured proteolytic activity was representative of the slow hydrolysis rate of the semi-labile pool (Mh2). The short-term sampling frequency permitted detection of a peak of DFAA during the first $50 \mathrm{~h}$ of experiment. However, in the model, MCA-Leu measurements were not compatible with the important fluxes of protein hydrolysis needed to reproduce this peak. MCA-Leu hydrolysis rates appeared to be more coherent with the slow hydrolysis rates of less labile organic matter (Mh2). We suggest that the high concentration of proteins in our sample was responsible for the induction of fast hydrolyzing enzymes which were not able to hydrolyze MCA-Leu. The $V_{\text {max }}$ per cell ratio being relatively constant showed that MCA-Leu hydrolysis was likely to be due to constitutive ectoproteases. In the biodegradation experiment, proteolytic fluxes were due to a combination of inducible (high activity with respect to the Mh1 pool during a first phase) and constitutive enzymes (lower activity with respect to the Mh2 pool, second phase). The assimilation technique, applied to the model, showed that the MCA-Leu poorly traced the hydrolysis of labile proteins.
\end{abstract}

KEY WORDS: Data assimılation Modelling B Biodegradation Ectoproteolytic activity $\cdot$ MCA-Leu

\section{INTRODUCTION}

In oceanic waters, bacterial processes involved in the transformation and mineralisation of organic matter are crucial parameters for carbon cycle predictions. If bacteria can directly use dissolved organic

- Addressee for correspondence.

E-mail:m-bianchi@luminy.univ-mrs.fr carbon (DOC), most of the utilizable fraction of this DOC is polymeric (Chróst 1990). The hydrolysis of polymeric organic matter is still a major process in the organic matter cycle as bacteria cannot transfer polymeric material through bacterial membranes. The assessment of the role of bacterial hydrolysis in organic matter fluxes is still a challenge as (1) the processes concern natural assemblages of bacteria, and (2) the coupling of hydrolysis (of polymers) and 
uptake (of monomers) are largely insufficiently studied (Azam et al. 1995).

To determine the relationships between natural organic matter behavior and bacterial activities, biodegradation experiments have been carried out (e.g. Sempéré et al. 1998). Such experiments are based on the seawater culture technique and involve the measurement of bacterial parameters, including biomass, production and organotrophic activities, and DOC concentration. The capability of bacteria to hydrolyze polymeric compounds can be determined through the measurement of proteolytic activity. Ectoproteolysis rates can be measured by using a fluorogenic substrate analog: MCA-Leu (L-leucine-4-methyl-7coumarinylamide) (Hoppe 1983, Chróst 1991a). This technique was developed as a way to directly measure natural ectoproteolytic kinetics and has become a cornerstone method in the field of microbial ecology (Chróst 1991a).

The HSB model ( $\mathrm{H}$ : concentration of polymers, $\mathrm{S}$ : monomeric substrate pool, and B: bacterial biomass) of Servais (1987), described in Billen \& Servais (1988) and Billen (1991), was run on the data sets of 1 biodegradation experiment carried out on Mediterranean seawater. Further, data assimilation was used by Lamy (1997) to determine the set of parameters which would give the best fit to the observed data. The appellation 'data assimilation' was chosen, instead of 'parameter optimization', 'nonlinear regression', or 'data fitting', because it draws attention to the data and it emphasizes a dynamic approach in ecological modelling. Indeed, data assimilation aims to improve forecasts of an existing model by adding the information which is contained in a new data set. In this paper, the optimization scheme mimimizes a cost function which measures the distance between the model response and the data. In other works (Fasham \& Evans 1995, Matear 1995), the cost function also includes additional terms that constrain parameters to be within a predefined range, so what is already known about the system is taken into account. When a data assimilation is performed, the accuracy of the model predictions is partly linked to a good interpretation of the used measurements.

A biodegradability experiment was carried out on a Mediterranean seawater sample. We measured simultaneously DOC, dissolved free amino acids (DFAA), bacterial biomass, and ectoproteolytic rates by means of the MCA-Leu technique. The HSB model was applied to the set of data to analyze the incoherencies and to better understand the significance of the ectoproteolytic activity estimates with respect to the governing processes.

\section{MATERIALS AND METHODS}

Experimental protocol and data management. The theoretical experimental protocol has already been described in detail in Sempéré et al. (1998). Briefly, 2 glass bottles (in duplicate) received $4.5 \mathrm{l}$ of $0.02 \mu \mathrm{m}$ filtered (Anodisc membrane filters) surface seawater collected in May 1994 in the Gulf of Marseille, and an inoculum of $0.5 \mathrm{l}$ of the same seawater filtered through $1 \mu \mathrm{m}$ Nuclepore filters. These microcosms were incubated in the dark at in situ temperature $\left(18^{\circ} \mathrm{C}\right)$ for $12 \mathrm{~d}$.

Bacteria were counted by epifluorescence microscopy and the number of cells was converted to biomass using $20 \mathrm{fg} \mathrm{C} \mathrm{cell}^{-1}$ (Lee \& Fuhrman 1987). Presence and abundance of bacterial predators (flagellates) were estimated by systematic observation of random $10 \mathrm{~mm}$ strips ( $160 \mu \mathrm{m}$ width) on the same slides as bacteria. DFAA were analyzed by high performance liquid chromatography after OPA (o-phthaldialdehyde) derivatization (Lindroth \& Mopper 1979), whereas DOC concentrations were measured by using a Shimadzu TOC-5000 functioning by high temperature combustion technique (Sharp et al. 1993, Yoro et al. 1997).

The ectoproteolytic activity was measured using the model substrate MCA-Leu (Hoppe 1983, Talbot \& Bianchi 1997). Two substrate concentrations were used: a trace concentration of $0.5 \mu \mathrm{M}$ measured the hydrolysis turnover rate, or $H_{\mathrm{r}}$ (velocity/substrate concentration), of the proteins present in our sample, and a saturation concentration of $200 \mu \mathrm{M}$ measured the maximum velocity, $V_{\max }$ of the Michaelis-Menten kinetic. In oligotrophic natural environments, this concentration is generally saturating. As MCA-Leu was used as a model substrate of proteins, $V_{\text {max }}$ was expressed in $\mu \mathrm{M} \mathrm{C} \mathrm{h}^{-1}$ using a $\mathrm{C}$ per mole ratio of 4.2 (i.e. average $C$ per mole ratio of amino acids) instead of the leucine ratio ( $6 C$ per mole leucine) 
Model. In the HSB model (Fig. 1), the organic matter (OM) is divided into 3 polymeric pools, i.e. the labile (Mh1), the semi-labile (Mh2) and the refractory (with respect to the experiment duration) (Mh3), and 1 monomeric pool (Ms). Mh1 and Mh2 are, respectively, quickly and slowly hydrolyzed into Ms. This $\mathrm{Ms}$ pool is composed of small organic compounds which are either assimilated into the bacterial pool (Mb) or mineralized in dissolved inorganic carbon. After their natural death, bacteria feed the Mh1 pool. Evolution equations of the 5 state variables are as follows:

$$
\begin{aligned}
\frac{\mathrm{dMhl}}{\mathrm{d} t}= & -e \mathrm{I}_{\max } \frac{\mathrm{Mh} 1}{\mathrm{Mh} 1+K \mathrm{hl}} \mathrm{Mb}+k d \times \mathrm{Mb} \\
\frac{\mathrm{dMh} 2}{\mathrm{~d} t}= & -e 2_{\max } \frac{\mathrm{Mh} 2}{\mathrm{Mh} 2+K \mathrm{~h} 2} \mathrm{Mb} \\
\frac{\mathrm{dMh} 3}{\mathrm{~d} t}= & 0 \\
\frac{\mathrm{dMs}}{\mathrm{d} t}= & -e \mathrm{I}_{\max } \frac{\mathrm{Mh}}{\mathrm{Mhl}+K \mathrm{hl}} \mathrm{Mb} \quad 2_{\max } \frac{\mathrm{Mh} 2}{\mathrm{Mh} 2+K \mathrm{~h} 2} \mathrm{Mb}-b_{\max } \frac{\mathrm{Ms}}{\mathrm{Ms}+K} \mathrm{Mb} \\
\frac{\mathrm{dMb}}{\mathrm{d} t}= & Y \times b_{\max } \frac{\mathrm{Ms}}{\mathrm{Ms}+K} \mathrm{Mb}-k d \times \mathrm{Mb}
\end{aligned}
$$

Table 1 describes the 8 model parameters and the 5 initial conditions which all constitute the control parameter vector $P$.

Parameter determination. Control parameters were determined using the Levenberg-Marquardt algorithm (Johnson \& Faunt 1992) to minimize the cost function:

$$
\operatorname{Cost}(P)=\sum\left(\frac{X_{i}-D_{1}}{E_{j}}\right)^{2}
$$

where $D_{i}$ is the $i$ th datum used to perform the assimilation with its corresponding standard deviation, $E_{i t}$ and $X_{i}$ corresponds to the estimate of the HSB model. This weighting method gives more weight to the more accurate data, whatever their absolute values are. A logarithmic transformation was used to constrain parameter values to be positive (Lamy 1997). At the beginning of the assimilation scheme, initial parameter values $\left(P_{\text {start }}\right)$ were estimated from the literature or from a previous assimilation. The following transformation equations were used to transform state variables into estimates $\left(X_{\mathrm{b}}, X_{\mathrm{DOC}}, X_{\mathrm{DFAA}}\right.$ and $\left.X_{H_{\mathrm{r}}}\right)$ which were compared to the data (bacterial biomass, DOC, DFAA and $H_{\mathrm{r}}$ respectively):

$$
\begin{aligned}
& X_{\mathrm{b}}=\mathrm{Mb} \\
& X_{\mathrm{DOC}}=\mathrm{Mh} 1+\mathrm{Mh} 2+\mathrm{Mh} 3+\mathrm{Ms} \\
& X_{\mathrm{DFAA}}=\mathrm{Ms} \\
& X_{H_{s}}=e 1_{\max } \frac{1}{\mathrm{Mh} 1+K \mathrm{~h} 1} \mathrm{Mb}
\end{aligned}
$$

Relationships between data and state variables are evident for bacterial biomass (Eq. 7) and DOC (Eq. 8). Eq. 9 means that there was 1 monomer for 1 DFAA in our experiment. This assumption will be debated in 'Results' as will the management of $H_{r}$ data (Eq. 10).

Solution analysis. The optimized parameter values corresponding to the assimilation solutions are denoted $P_{\text {opl }}$. Each optimized parameter is presented in the following way:

$$
P_{\mathrm{opt}} \pm S_{\mathrm{tij}} \%_{\mathrm{o}} \times F_{j} \times S_{\mathrm{sys}}
$$

where the term-to-term indetermination, $S_{11 j}$ (expressed as a percentage of the parameter value), and the correlation inflation factor, $F_{j}$, are calculated for each parameter using the covariance matrix. The systematic indetermination, $S_{\text {sys }}$ equally applied to every parameter, is defined by the following equation:

$$
S_{s y s}=\sqrt{\frac{\operatorname{Cost}\left(P_{\text {opt }}\right)}{v}}
$$

where $v$ is the number of degrees of freedom of the regression, that is the number of data minus the number of control parameters (here 13). Lamy (1997) demonstrated that $S_{\mathrm{tij}} \% \times \mathrm{F}_{j} \times S_{\mathrm{sys}}$ is the best known estimator of the global indetermination on $P_{\mathrm{opt} j}$, that is the linear approximation standard error as described in Watts (1994).

Each term of the global indetermination gives specific information to the modeler. $S_{\text {sys }}$ measures the distance in $\sigma$ between the model response and data, and is an indicator of the goodness of fit. Its value should be equal to 1 when data standard deviations are well estimated. A high $S_{\text {sys }}$ value would indicate that the model (Eqs. 1 to 5 ) or the transformation function (Eqs. 7 to 10) may be inadequate. Attempts would then be made to discover where and how the inadequacy occurs. The model response should go through data error bars and no gap should appear between curves and a group of data.

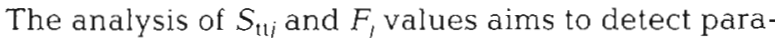
meter underdeterminations due to a lack of data. $S_{1 \mathrm{tj}}$ is the $1 \sigma$ confidence interval along the $P_{j}$ axis when the other parameters are fixed to their optimized values. A high $S_{t t j}$ value indicates that $P_{j}$ is not sensitive to the data selection (i.e. data used to perform the assimilation). A high $F_{j}$ value indicates that data did not constrain $P_{j}$ alone, but 1 or several parameter combinations which include $P_{j}$. The $F_{j}$ value equals 1 if $P_{j}$ is uncorrelated and it could be nearly infinite if $P_{j}$ is strongly correlated with at least another parameter. $S_{(1)}$ $\times F_{j}$ determines the extreme values that $P$, can take in the $1 \sigma$ confidence ellipsoid when the correlated parameters are modified in a definite way.

To measure the misfit between the model response and part of the data, we use the root mean square value: 
Table 1 Definition of control parameters ( 5 initial conditions and 8 model parameters) used in the HSB model

\begin{tabular}{|lcl|}
\hline $\begin{array}{l}\text { Control } \\
\text { parameter }\end{array}$ & Units & \multicolumn{1}{c|}{ Definition } \\
\hline $\mathrm{Mh} 1\left(t_{0}\right)$ & $\mu \mathrm{MC}$ & Initial condition of very labile polymers \\
$\mathrm{Mh} 2\left(t_{0}\right)$ & $\mu \mathrm{MC}$ & Initial condition of labile polymers \\
$\mathrm{Mh} 3\left(t_{0}\right)$ & $\mu \mathrm{MC}$ & Initial condition of refractory polymers \\
$\mathrm{Ms}\left(t_{0}\right)$ & $\mu \mathrm{MC}$ & Initial condition of monomers \\
$\mathrm{Mb}\left(t_{0}\right)$ & $\mu \mathrm{MC}$ & Initial condition of bacterial biomass \\
$e 1_{\max }$ & $\mathrm{h}^{-1}$ & Maximum hydrolysis rate of very labile polymers \\
$K \mathrm{~h} 1$ & $\mu \mathrm{MC}$ & Half saturation of very labile polymers hydrolysis \\
$e 2_{\max }$ & $\mathrm{h}^{-1}$ & Maximum hydrolysis rate of labile polymers \\
$\mathrm{Kh} 2$ & $\mu \mathrm{MC}$ & Half saturation of labile polymers hydrolysis \\
$\mathrm{b}_{\max }$ & $\mathrm{h}^{-1}$ & Maximum uptake \\
$K_{\mathrm{s}}$ & $\mu \mathrm{MC}$ & Half saturation constant of uptake \\
$Y$ & & Growth yield \\
$k d$ & $\mathrm{~h}^{-1}$ & Mortality rate \\
\hline
\end{tabular}

In the duplicate batches, the bacterial biomass, proteolytic activity ( $V_{\text {max }}$ and $H_{r}$ ), DOC and DFAA showed the same evolution with time (Fig. 2). The average variation between the parameters measured at the same sampling time in the duplicate batches was $13 \%$ for bacterial biomass, $4 \%$ for $V_{\max }$ ectoproteolytic activity, $5 \%$ for in situ turnover rate $\left(H_{\mathrm{r}}\right), 9 \%$ for DOC and $28 \%$ for DFAA concentrations. In duplicates, a DFAA peak was simultaneously observed between 22 and $45 \mathrm{~h}$ (Fig. 2), but with different amplitudes.

To compare the state variables to the data, we assumed that there was 1 monomer for 1 DFAA in our experiment. This assumption gave the best fit to the combined data set: bacterial biomass, DOC and DFAA (Lamy 1997). When assuming 2 monomers for 1 DFAA, a more impor-

$$
\operatorname{RMS}=\sqrt{\frac{1}{N} \sum\left(\frac{X_{i}-D_{i}}{E_{i}}\right)^{2}}
$$

where the summation is performed over the $N$ data which are compared to the model.

\section{RESULTS}

Some flagellates were enumerated in the batches at the end of the experiment, up to $2 \times 10^{3}$ flagellates $\mathrm{ml}^{-1}$, and they were responsible for a strong decrease of the bacterial abundance after $200 \mathrm{~h}$. As grazing processes were not included in the modelling, data corresponding to this period were not selected for the assimilations. tant labile pool, Mh1 $\left(t_{0}\right)$, was needed to reproduce the DFAA peak (Fig. 3c); but Mh1(t $\left.t_{0}\right)$ was limited by the DOC concentrations which were consumed during the first $2 \mathrm{~d}$ of the experiment (Fig. 3b). As DFAA are the products of protein hydrolysis, the equivalence between DFAA and monomers at the beginning of the experiment indicated that the labile pool Mh1 was mainly composed of proteins. The equivalence between DFAA and the Ms pool (Eq. 9) was no longer valid after the first $2 \mathrm{~d}$ of the experiment when the proteinaceous pool Mh1 was depleted. This was not cumbersome because the late DFAA concentrations were near the noise threshold level $(0.5 \mu \mathrm{M} \mathrm{C})$ and their relative weights in the cost function were very low (Eq. 6). With regard to the management of $H_{\mathrm{r}}$ data, Eq. 10 means that we compared the calculated hydrolysis
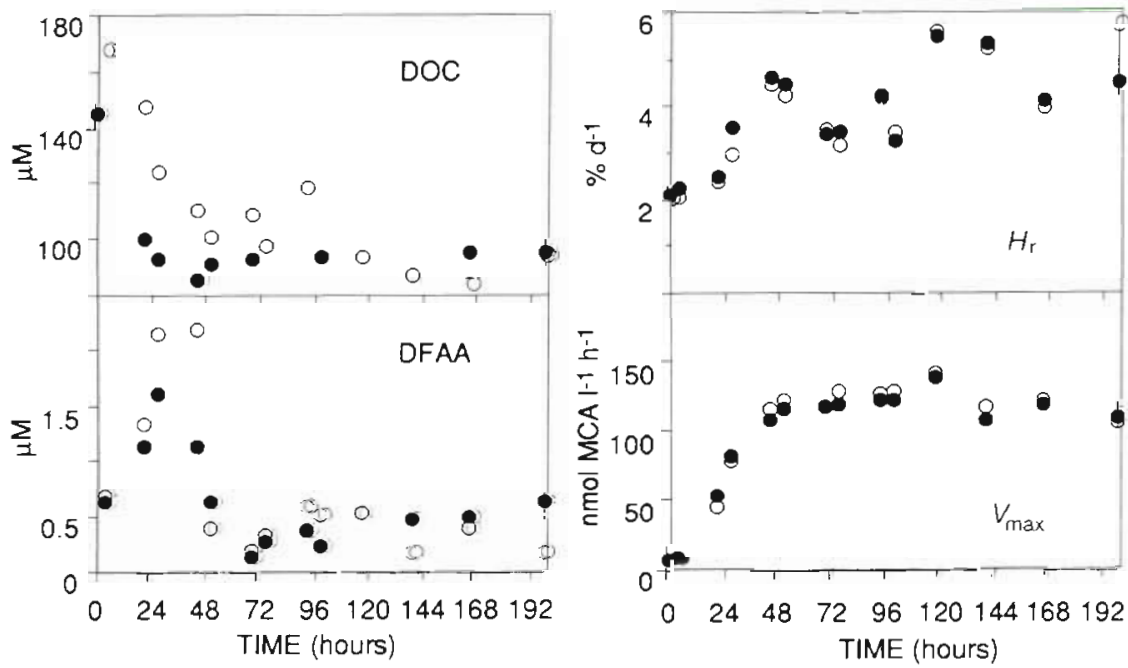

Fig. 2. Comparison of data sets from the replicate batches. See text for definitions 
fluxes (Eq. 1) to the 'measured fluxes' $H_{\mathrm{r}} \times \mathrm{Mh} 1(t)$. This relies on 2 assumptions: that MCA-Leu was a model substrate of the proteinaceous pool Mh1 and that MCA-Leu was used in trace concentrations
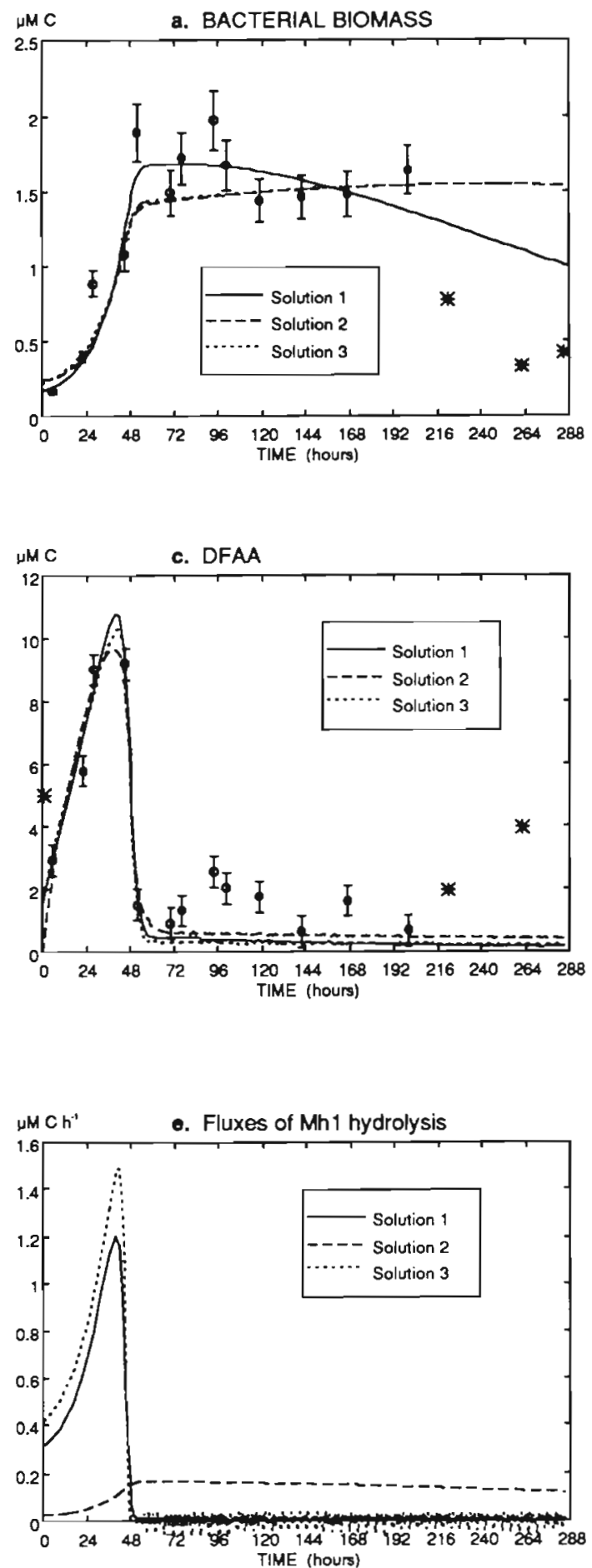

\section{Solution 1}

The first assimilation was performed without $H_{\mathrm{r}}$ data (Table 2). Fig. 3a,b,c shows that the selected data (bac-
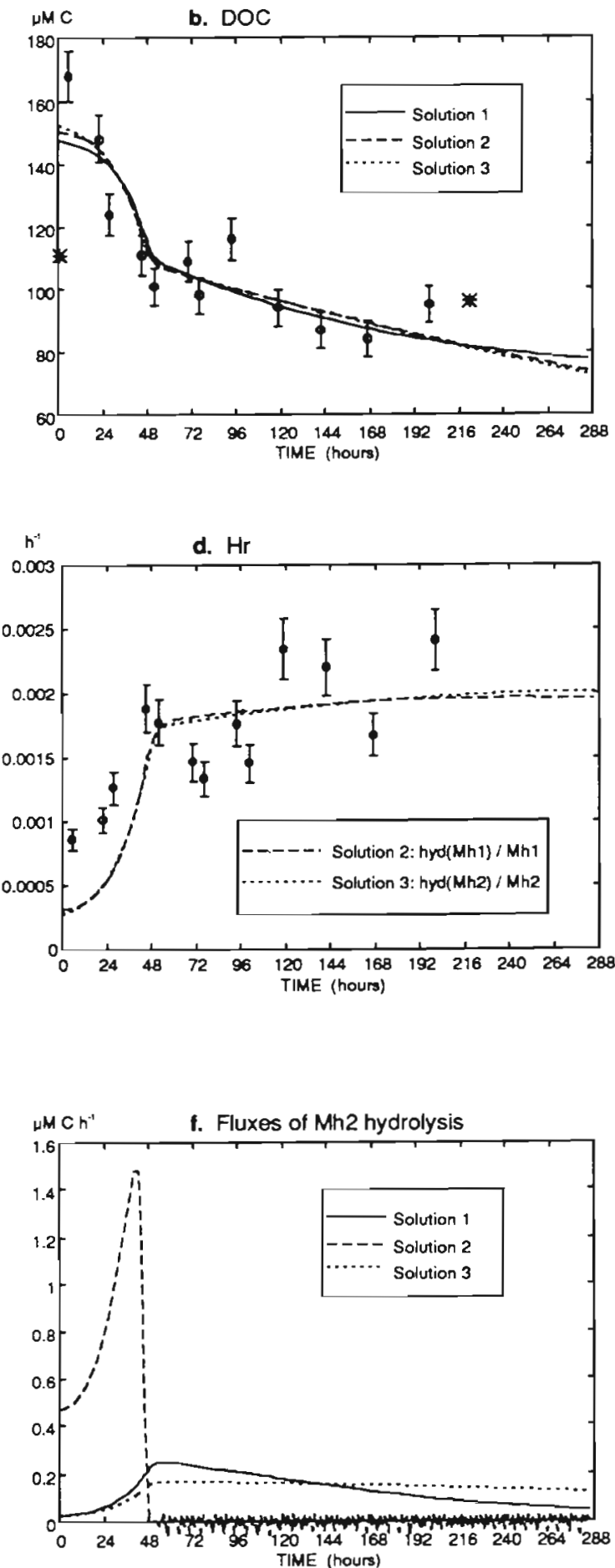

Fig. 3. Data and model responses: (0) selected data with the corresponding $1 \sigma$ error bars; (*) non selected data; curves show model responses. Data standard deviations correspond to $10 \%$ measurement for bacterial biomass, $3 \%$ measurement plus $3 \mu \mathrm{M} C$ for DOC, $0.5 \mu \mathrm{MC}$ for DFAA, and $10 \%$ measurement for $H_{r}$. Non selected data correspond to grazing at the end of the experiment 
Table 2. Assimilation solutions. All 3 assimilations were performed with bacterial biomass, DOC and DFAA measurements. Exoproteolytic activities $\left(H_{\mathrm{r}}\right)$ were used to obtain Solutions 2 and 3 , but not Solution 1. Parameter value and indeterminations: $P_{\mathrm{opt}} \pm$ $S_{11} \% \times F, \times S_{5 y 9}$, where $S_{11,} \%$ is the term-to-term indetermination (percentage of parameter value), $F$, is the correlation inflation factor, and $S_{x y s}$ is the systematic indetermination which is equally applied to every parameter. See text for details and definitions

\begin{tabular}{|c|c|c|c|c|c|}
\hline & & $S_{\text {sys }}:$ & $\begin{array}{l}\text { Solution } 1 \\
\text { without } H_{\mathrm{r}} \\
\quad \times 2.2\end{array}$ & $\begin{array}{l}\text { Solution } 2 \\
\text { with } H_{\mathrm{r}} \text { compared to } \\
\text { Mh1 hydrolysis } \\
\times 2.7\end{array}$ & $\begin{array}{c}\text { Solution } 3 \\
\text { with } H_{\mathrm{r}} \text { compared to } \\
\text { Mh2 hydrolysis } \\
\times 2.7\end{array}$ \\
\hline $\operatorname{Mh} 1\left(t_{0}\right)$ & $\mu \mathrm{MC}$ & & $32 \pm 1 \% \times 16^{\mathrm{d}}$ & $98 \pm 2 \% \times 8$ & $40 \pm 2 \% \times 7$ \\
\hline $\operatorname{Mh} 2\left(t_{0}\right)$ & $\mu \mathrm{MC}$ & & $46 \pm 4 \% \times 9$ & $40 \pm 2 \% \times 6$ & $100 \pm 2 \% \times 10$ \\
\hline $\operatorname{Mh} 3\left(t_{0}\right)$ & $\mu \mathrm{MC}$ & & $68 \pm 2 \% \times 17$ & $12 \pm 15 \% \times 8$ & $11 \pm 16 \% \times 10$ \\
\hline $\operatorname{Ms}\left(t_{0}\right)$ & $\mu \mathrm{MC}$ & & $1.5 \pm 11 \% \times 5$ & $0 \pm 16000 \% \times 3$ & $1.5 \pm 14 \% \times 4$ \\
\hline $\mathrm{Mb}\left(t_{0}\right)$ & $\mu \mathrm{M} \mathrm{C}$ & & $0.18 \pm 2 \% \times 6$ & $0.25 \pm 2 \% \times 4$ & $0.22 \pm 1 \% \times 5$ \\
\hline$e 1_{\max }$ & $\mathrm{h}^{-1}$ & & $2.0 \pm 1 \% \times 11$ & $5.3 \pm 2 \% \times 1030$ & $1.9 \pm 2 \% \times 5$ \\
\hline$K \mathrm{~h} 1$ & $\mu \mathrm{MC}$ & & $3.4 \pm 3 \% \times 20$ & $4107 \pm 2 \% \times 1030$ & $1.3 \pm 5 \% \times 3$ \\
\hline$e 2_{\max }$ & $\mathrm{h}^{-1}$ & & $0.48 \pm 6 \% \times 69$ & $2.0 \pm 2 \% \times 6$ & $0.67 \pm 2 \% \times 130$ \\
\hline Kh2 & $\mu \mathrm{MC}$ & & $90 \pm 9 \% \times 68$ & $1.7 \pm 11 \% \times 4$ & $452 \pm 3 \% \times 130$ \\
\hline$b_{\max }$ & $h^{-1}$ & & $2.3 \pm 1 \% \times 51$ & $73 \pm 2 \% \times 483$ & $2.8 \pm 1 \% \times 31$ \\
\hline$K_{s}$ & $\mu \mathrm{MC}$ & & $6.3 \pm 2 \% \times 44$ & $376 \pm 2 \% \times 482$ & $6.8 \pm 3 \% \times 27$ \\
\hline$Y$ & & & $0.044 \pm 1 \% \times 16$ & $0.029 \pm 1 \% \times 9$ & $0.029 \pm 1 \% \times 12$ \\
\hline$k d$ & $h^{-1}$ & & $0.0064 \pm 5 \% \times 7$ & $0.0025 \pm 10 \% \times 4$ & $0.0026 \pm 9 \% \times 5$ \\
\hline
\end{tabular}

terial biomass, DOC and DFAA) were well reproduced. At the beginning of the experiment, the hydrolysis of the proteinaceous pool Mh1 was faster than the bacterial uptake of monomers, so DFAA accumulated, producing a peak (Fig. 3c). After $2 \mathrm{~d}$, Mh1 was depleted, all the monomers were consumed in a few hours, and the bacterial biomass reduced its growth. Then, 2 slow processes started to govern the evolution of bacterial biomass: the hydrolysis of the less labile pool Mh2 which sustained bacterial growth, and the mortality which led to a decrease of the bacterial biomass.

The only evident misfit was observed for the last 8 DFAA concentration measurements, but this misfit has little impact on the $S_{\text {Sys }}$ value because of the high relative errors of these data. Low $S_{i j}$ values of the first solution showed that every parameter was sensitive to the data selection. High $F_{j}$ values correspond to correlations between Michaelis-Menten parameters because of missing data near saturation (Berges et al. 1994).

\section{Solution 2}

The second assimilation was similar to the first assimilation, but turnover rate $\left(H_{r}\right)$ data were added in the cost function. $H_{\mathrm{r}}$ data were compared to Mh1 hydrolysis fluxes as described in Eq. (10). $P_{\text {start }}$ values were the optimized values of the first solution. Fig. $3 a-d$ shows that DOC, DFAA and $H_{r}$ data were well fitted, and that there was a little deterioration of the adjustment to bacterial biomass. This deterioration was due to the introduction of $H_{r}$ data in the data selec- tion, which generated some discrepancies between the different data types. The misfit with some bacterial biomass data and the underestimation of $H_{\mathrm{r}}$ standard deviations (Fig. 3 d) caused an increase of the $S_{\text {sys }}$ value between the first and the second solution ( 2.2 and $2.7 \mathrm{\sigma}$ respectively). Table 3 confirms that the $S_{\text {sys }}$ increase was due to these 2 reasons. Yet this increase is not very important, and the model response seemed globally coherent.

On the contrary, optimized parameter values were very different between the first and the second assimilations (Table 2). The main difference is that the fast hydrolysis became the slow hydrolysis, and vice versa. Even if the equations of the 2 hydrolysis kinetics were potentially identical (Eqs. $1 \& 2$ ), this is surprising if we recall that $P_{\text {start }}$ values were $P_{\text {opt }}$ values of the first solution. Fig. $3 e$, emphasizes the exchange between the hydrolysis fluxes of Mh1 and Mh2. The DFAA peak was no longer produced by the hydrolysis of $\mathrm{Mh} 1$, but by the hydrolysis of Mh2. As a consequence, Mh1 no longer corresponded to the proteinaceous pool. This result is inconsistent with the hypothesis that MCA-

Table 3. Root Mean Square (RMS) values for each data type. For each data type, the RMS value is calculated with all the data used to perform the assimilations

\begin{tabular}{|lccc|}
\hline & Solution 1 & Solution 2 & Solution 3 \\
\hline RMS $_{\mathrm{b}}$ & 1.7 & 2.2 & 2.1 \\
RMS $_{\text {DOC }}$ & 1.6 & 1.5 & 1.5 \\
RMS $_{\text {DFAA }}$ & 2.1 & 2.1 & 2.2 \\
RMS $_{H_{r}}$ & - & 3.2 & 3.2 \\
\hline
\end{tabular}


Leu is a model substrate of rapidly hydrolyzed proteins: we compared $H_{r}$ measurements to Mh1 hydrolysis fluxes (Eq. 10) and $H_{\mathrm{r}}$ data were not compatible with the production of DFAA coming from proteins being quickly hydrolyzed.

At the beginning of the assimilation scheme, the very high cost function value $\left[\operatorname{Cost}\left(\mathrm{P}_{\text {start }}\right)=3 \times 10^{8}\right.$. where $P_{\text {start }}$ values corresponded to $P_{\text {opt }}$ values of the first solution] underlines the incompatibility of $H_{\mathrm{r}}$ data with the fast hydrolysis fluxes of the first solution. Contribution of the other data (bacterial biomass, DOC, DFAA) to this value was very weak, as denoted by the low $\operatorname{Cost}\left(P_{\text {opt }}\right)$ value of the first solution (=126). Because of the important gap between the initial model response and data, the poorly constrained parameters were allowed to change without reason. So, the slow hydrolysis and uptake parameters took abnormally high values (Table 2). The corresponding $F$, values were high because substrate concentrations became negligible with respect to $K \mathrm{~h} 1$ and $K_{s}$ values.

\section{Solution 3}

The third assimilation was performed assuming that $H_{\mathrm{r}}$ measurements were representative of the slow hydrolysis rate of $\mathrm{Mh} 2$, so the following equation was used instead of Eq. (10):

$$
X_{H_{r}}=e 2_{\max } \frac{1}{\mathrm{Mh} 2+K \mathrm{~h} 2} \mathrm{Mb}
$$

$P_{\text {start }}$ values were the same as the ones used for the second assimilation. The better agreement of $H_{r}$ data with the slow hydrolysis than with the fast hydrolysis was confirmed by a $\operatorname{Cost}\left(P_{\text {star }}\right)$ value of $7 \times 10^{3}$ instead of $3 \times$ $10^{8}$ for the second assimilation. The $S_{\text {sys }}$ value (Table 2) and Fig. $3 a-d$ show that data adjustment was similar to the second solution. But, in contrast to the second solution, Fig. 3e,f emphasizes that Mh1 and Mh2 hydrolysis fluxes were coherent with the fluxes of the first solution.

A decrease of $S_{t 1 j}$ values between the first and the third solutions could only be observed for the slow hydrolysis parameters $e 2_{\max }$ and $K$ h2 (Table 2). This means that the additional $H_{\mathrm{r}}$ data constrained only the 2 parameters corresponding to the slow hydrolysis kinetic. High $F$ values show that these parameters are very correlated. This is a limitation in our experiment where substrate concentrations were within the linear part of the Michaelis-Menten kinetic. Mh2 concentrations were low compared to $K$ h2 values (Table 2 ), and Eq. (14) shows that $H_{\mathrm{r}}$ data constrained only the $e 2_{\max } / K$ h2 ratio. A lower $e 2_{\max } / K h 2$ value indicates a hydrolysis rate in the third solution $\left(0.0015 \mu \mathrm{M} \mathrm{C} \mathrm{h}^{-1}\right)$ lower than that in the first solution $\left(0.0053 \mu \mathrm{M} \mathrm{C} \mathrm{h}^{-1}\right)$.
This lower hydrolysis rate induced a higher Mh2( $\left.t_{0}\right)$ concentration $(100 \mu \mathrm{M} \mathrm{C})$ to reproduce DOC decrease after Mh1 depletion (Fig. 3b). Eqs. (7) \& (14) forced $X_{\mathrm{b}}$ to be proportional to $X_{H_{\mathrm{r}}}$ so $X_{\mathrm{b}}$ (Fig. 3a) increased similarly to $X_{H_{\mathrm{r}}}$ (Fig. $3 \mathrm{~d}$ ) for the duration of the entire experiment. This explains why the mortality parameter $k d$ is lower than in the first solution (Table 2). As a consequence, the $Y$ value was lowered to compensate for lower mortality loss.

\section{DISCUSSION}

At the beginning of our biodegradation experiment, the important release of DFAA in the microcosm demonstrated high rates of ectoproteolytic enzyme activity. Such rates of proteolysis could be related to the high initial concentration of proteins established by the model as $\mathrm{Mh} 1\left(t_{0}\right)=32 \mu \mathrm{MC}$ in the first assimilation, providing conditions able to induce ectoproteases (Chróst \& Rai 1993). However, we were not able to measure this initial high activity with the MCA-Leu technique.

In the estimation of in situ protein hydrolysis rates, few attempts have been made to combine ectoproteolytic activity estimated by MCA-Leu with dissolved combined amino acids (Delmas et al. 1994) or particulate organic nitrogen (PON, Hoppe et al. 1993). However, these attempts have not been generalized. Indeed, these authors underlined the biases of their estimates: the molecular structure of PON and dissolved organic nitrogen (DON) are not completely identified and it is not known to what extent the specificity of the enzyme acting on the substrate has a broad or narrow spectrum. Pantoja et al. (1997) showed that longer peptides were hydrolyzed faster than small dipeptides, and that MCA-Leu was hydrolyzed at rates similar to those of dipetides. A calibration between MCA-Leu hydrolysis and in situ proteolysis rates does not presently seem feasible because the quantity and composition of natural substrates are not known, and neither are the OM fractions which are best represented by the substrate analog (Chróst \& Rai 1993, Hoppe et al. 1993, Martinez \& Azam 1993). In agreement with the above remarks, several authors have underlined the inadequacy of artificial fluorogenic substrates to estimate in situ fluxes, and have restricted the use of MCA-Leu measurements as relative indicators of aminopeptidase activities and/or used kinetic properties $\left(V_{\text {max }}, K_{\text {max }}\right)$ to compare activities (Halemejko \& Chróst 1986, Chróst \& Rai 1993, Martinez \& Azam 1993).

Moreover, in the biodegradation experiment, the mean value of the $V_{\max }$ /bacterial biomass ratios, calculated over the whole data set, was $0.35 \pm 0.08 \mathrm{~h}^{-1}$. The low standard deviation indicates that, through the low variation of this ratio, the ectoproteolytic activities measured with the MCA-Leu substrate were propor- 
tional to bacterial biomass. We are aware that saturating conditions were not verified for each sample, leading to a possible underestimate of $V_{\max }$ at the end of the experiment. However, it can be suggested that MCALeu measurements were representative of the activity of constitutive proteases. Note that the $0.35 \mathrm{~h}^{-1}$ value is coherent with $e 2$ max values of the first and the third solutions $\left(0.48 \mathrm{~h}^{-1}\right.$ and $0.67 \mathrm{~h}^{-1}$ respectively). The corresponding per-cell MCA-Leu hydrolysis rate $(138 \times$ $10^{-18}$ mol MCA cell-1 $\mathrm{h}^{-1}$ ) is higher than the range generally found for bacteria from the open sea $(10-70 \times$ $10^{-18} \mathrm{~mol} \mathrm{MCA} \mathrm{cell}{ }^{-1} \mathrm{~h}^{-1}$ ) (Hoppe 1983, Rosso \& Azam 1987), but within the range reported for bacteria from lakes, rivers, marine lagoons and coastal marine ponds $\left(100-600 \times 10^{-18} \mathrm{~mol} \mathrm{MCA} \mathrm{cell}{ }^{-1} \mathrm{~h}^{-1}\right.$ ) (Hoppe et al. 1988, Chróst et al. 1989, Admiraal \& Tubbing 1991, Delmas et al. 1994).

Even if MCA-Leu measurements seem coherent with the slow hydrolysis kinetics, the analysis of the third solution raised some anomalies. $H_{\mathrm{r}}$ measurements constrained the slow hydrolysis to be very slow. leading to a high Mh2 $\left(t_{0}\right)$ concentration $(100 \mu \mathrm{M} \mathrm{C})$ at the expense of the organic matter refractory pool $\left[\mathrm{Mh} 3\left(t_{0}\right)=11 \mu \mathrm{MC}\right]$. Using parameter values of the third solution, we found that the final $X_{\mathrm{DOC}}$ concentration was only $39 \mu \mathrm{M} \mathrm{C}$ after 1 mo of simulation. This concentration is very low compared to the in situ refractory pool which can be estimated from deep water concentrations. In the 150 to $2000 \mathrm{~m}$ layer of the North-Western Mediterranean Sea, Copin-Montégut \& Avril (1993) found that DOC distribution was quite uniform, with a content of about 50 to $58 \mu \mathrm{M} C$. Thus, the use of MCA-Leu might measure only a part of the slow hydrolysis. This part could be representative of the hydrolysis of a fraction of Mh2 composed of less labile proteins and/or macromolecular complexes.

One can wonder if the underestimation of the slow hydrolysis rate was due to a non-negligible MCA-Leu concentration used to perform $H_{\Gamma}$ measurements (2.1 $\mu \mathrm{M} \mathrm{C}$ using a $\mathrm{C} \mathrm{mol}^{-1}$ ratio of 4.2 ). Activity measurements would be altered significantly if the MCALeu concentration was not negligible with respect either to $\mathrm{Mh} 2$ concentrations or to $K \mathrm{~h} 2$ values. In our experiment, we considered that MCA-Leu was actually present in trace concentration with regard to the Mh2 concentration at the end of the experiment (61 $\mu \mathrm{M} \mathrm{C}$ for the third solution).

Results of this study suggest that dominant proteolytic fluxes occurring in the biodegradation experiment were due to a combination of inducible and constitutive proteases. Both systems have been previously described (Chróst 1990). Chróst (1991b) and Chróst \& Rai (1993) argued that ectoproteases are inducible enzymes because enzymatic activity measurements fluctuate with environmental conditions. On the con- trary, Martinez \& Azam (1993) found that aminopeptidase of Synechococcus spp. was constitutive because per-cell activity (measured with MCA-Leu) did not change during incubations in unenriched seawater, bovine serum albumin, or nitrate-replete mineral medium. If induction is one mechanism explaining fluctuations of in situ measurements, differences in ectoproteolytic activity responses are also due to different bacterial populations which are representative of different ecosystem status and possess different enzymatic systems. From samples from the North Atlantic Ocean, Hoppe et al. (1993) found that peptidase potential (measured with MCA-Leu) per unit cell biomass of mesopelagic bacteria was 2 to 3 times higher than that of bacteria of surface water. This is consistent with our finding that MCA-Leu poorly traces the hydrolysis of fresh labile proteins which are consumed as soon as produced. Moreover, their result supports the hypothesis that mesopelagic bacteria are adapted to the use of moderately labile material (i.e. our Mh2 pool) which can reach deeper layers.

By testing coherency between MCA-Leu measurements and other data, data assimilation demonstrated that the MCA-Leu technique underestimated hydrolysis rates of labile proteins in our experiment. More biodegradation experiments, including additional measurements, such as measurements of dissolved combined amino acids, are needed to improve these results and the forecasts of the model. The experiments should be scheduled with a high sampling frequency during the first 2 to $3 \mathrm{~d}$, permitting detection of the occurrence of short-term events like peaks of low molecular weight compounds due to fast hydrolysis processes.

Such transient events are very difficult to point out in natural environments. Episodic events like grazing (Andersson et al. 1985, Nagata \& Kirchman 1992), or metabolically driven mechanisms like detritus hydrolysis (Smith et al. 1992) or phytoplankton autolysis and exudation (Carlucci et al. 1984), create 'hot spots' (Azam \& Ammerman 1984, Azam et al. 1995) providing proteins for hydrolysis. Estimates of in situ proteolysis fluxes from MCA-Leu measurements may be, as was demonstrated by experimentation, greatly underestimated.

Acknowledgements. We thank Danielle Mazaudier for technical analysis. We are also pleased to thank Dr Daniel Delmas and anonymous reviewers for their helpful comments. This research has been undertaken in the framework of the Mediterranean Targeted project (MTP) - EMPS project. We acknowledge the support of the European Commission's Marine Science and Technology (MAST) Programme under contract MAS2-CT94-0090. This study was also supported by a grant of the Centre National de la Recherche Scientifique (Modelling Operation of JGOFS-France). 


\section{LITERATURE CITED}

Admiraal W. Tubbing GMJ (1991) Extracellular enzyme activity associated with suspended matter in the River Rhine Freshw Biol 26:507-517

Andersson A, Lee C, Azam F, Hagström A (1985) Release of aminoacids and inorganic nutrients by heterotrophic marine microflagellates. Mar Ecol Prog Ser 23:99-106

Azam F, Ammerman JW (1984) Cycling of organic matter by bacterioplankton in pelagic marine ecosystems: microenvironmental considerations. In: Fasham MJR (ed) Flows of energy and material in marine ecosystems --theory and practice. NATO Conference Series, Plenum Press, New York, p 345-360

Azam F, Smith DC, Long RA, Steward GF (1995) Bacteria in oceanic carbon cycling as a molecular problem. In: Joint I (ed) Molecular ecology of aquatic microbes. Springer-Verlag, New York, p 39-54

Berges JA, Montagnes DJS, Hurd CL, Harrison PJ (1994) Fitting ecological and physiological data to rectangular hyperbolae: a comparison of methods using Monte Carlo simulations. Mar Ecol Prog Ser 114:175-183

Billen G, Servais P (1988) Modélisation des processus de dégradation bactérienne de la matière organique en milieu aquatique. In: Bianchi $M$, Marty D, Bertrand JC, Caumette P, Gauthier M (eds) Micro-organismes dans les écosystèmes océaniques. Masson, Paris, p 219-245

Carlucci AF, Craven DB, Henrichs SM (1984) Diel production and microheterotrophic utilization of dissolved free amino acids in waters off southern California. Appl Environ Microbiol 48:165-170

Chróst RJ (1990) Microbial ectoenzymes in aquatic environments. In: Overbeck J, Chróst RJ (eds) Aquatic microbial ecology. Biochemical and molecular approaches. Springer-Verlag, New York, p 47-78

Chróst RJ (1991a) Environmental control of the synthesis and activity of aquatic microbial ectoenzymes. In: Chróst RJ (ed) Microbial enzymes in aquatic environments. Springer-Verlag, New York, p 29-59

Chróst RJ (1991b) Ectoenzymes in aquatic environments: microbial strategy for substrate supply. Verh Int Verein Limnol 24:2597-2600

Chróst RJ, Rai H (1993) Ectoenzyme activity and bacterial secondary production in nutrient-impoverished and nutrientenriched freshwater mesocosms. Microb Ecol 25:131-150

Chróst RJ, Münster U, Rai H, Albrecht D, Witzel PK, Overbeck J (1989) Photosynthetic production and exoenzymatic degradation of organic matter in the euphotic zone of a eutrophic lake. J Plankton Res 11:223-242

Copin-Montégut G, Avril B (1993) Vertical distribution and temporal variation of dissolved organic carbon in the NorthWestern Mediterranean Sea. Deep-Sea Res 40:1963-1972

Delmas D, Legrand C, Bechemin C, Collinot C (1994) Exoproteolytic activity determined by flow injection analysis: its potential importance for bacterial growth in coastal marine ponds. Aquat Living Resour 7:17-24

Fasham MJR, Evans GT (1995) The use of optimization techniques to model marine ecosystem dynamics at the JGOFS station at $47^{\circ} \mathrm{N} 20^{\circ} \mathrm{W}$. Philos Trans R Soc Lond B 348 . 203-209

Halemejko GZ, Chróst RJ (1986) Enzymatic hydrolysis of proteinaceous particulate and dissolved material in an eutrophic lake. Arch Hydrobiol 107:1-21

Hoppe HG (1983) Significance of exoenzymatic activities in the ecology of brackish water: measurement by means of methylumbelliferyl-substrates. Mar Ecol Prog Ser 11: 299-308

Hoppe HG, Schramm W, Bacolod P (1988) Spatial and temporal distribution of pelagic microorganisms and their proteolytic activity over a partly destroyed coral reef. Mar Ecol Prog Ser 44:95-102

Hoppe HG, Ducklow H, Karrasch B (1993) Evidence for dependency of bacterial growth on enzymatic hydrolysis of particulate organic matter in the mesopelagic ocean. Mar Ecol Prog Ser 93:277-283

Johnson ML, Faunt LM (1992) Parameter estimation by leastsquares methods. Methods Enzymol 210:1-37

Lamy F (1997) Dégradation bactérienne de la matière organique en milieu marin: simulation au site EUMELI oligotrophe avec un modèle 1D-Assimilation de données expérimentales dans un modèle $0 \mathrm{D}$. Université de la Méditerranée-Aix-Marseille II

Lee S, Fuhrman JA (1987) Relationships between biovolume and biomass of naturally derived marine bacterioplankton. Appl Environ Microbiol 53:1298-1303

Lindroth P, Mopper K (1979) High performance liquid chromatographic determination of subpicomole amounts of amino acids by precolumn fluorescence derivatization with o-phthaldialdehyde. Anal Chem 51:1667-1674

Matear RJ (1995) Parameter optimization and analysis of ecosystem models using simulated annealing: a case study at Station P. J Mar Res 53:571-607

Martinez J, Azam F (1993) Aminopeptidase activity in marine chroococcoid cyanobacteria. Appl Environ Microbiol 59: $3701-3707$

Nagata T, Kirchman DL (1992) Release of macromolecular organic complexes by heterotrophic marine flagellates. Mar Ecol Prog Ser 83:233-240

Pantoja S, Lee C, Marecek JF (1997) Hydrolysis of peptides in seawater and sediment. Mar Chem 57:25-40

Rosso AL, Azam F (1987) Proteolytic activity in coastal oceanic waters: depth distribution and relationship to bacterial populations. Mar Ecol Prog Ser 41:231-240

Sempéré R, Van Wambeke F, Azourmanian $\mathrm{H}$, Chambaut AL, Ferrière L, Bianchi M (1998) On the use of batch systems to determine DOC bacterial lability and bacterial growth efficiency in seawater samples. In: Baeyens $J$, Dehairs $F$, Goeyens L (eds) Integrated marine system analysis. Vrije Universiteit Brussel, Brussels, p 223-238

Servais P (1987) Etude de la dégradation de la matière organique par les bactéries hétérotrophes en rivière. PhD thesis, Université Libre de Bruxelles, Brussels

Sharp JH, Benner R, Bennett L, Carlson CA, Dow R, Fitzwater SE (1993) Re-evaluation of high temperature combustion and chemical oxidation measurements of dissolved organic carbon in seawater. Limnol Oceanogr 38:1774-1782

Smith DC, Simon M, Alldredge AL, Azam. F (1992) Intense hydrolytic enzyme activity on marine aggregates and implications for rapid particle dissolution. Nature 359: $139-142$

Talbot V, Bianchi M (1997) Bacterial proteolytic activity in sediments of the Subantarctic Indian Ocean sector. DeepSea Res 44:1069-1084

Watts DG (1994) Parameter estimates from nonlinear models. Methods Enzymol 240:23-36

Yoro SC, Sempéré R, Turley C, Unanue MA, Durrieu de Madron X, Bianchi $M$ (1997) Cross-slope variations of organic carbon and bacteria in the Gulf of Lion in relation to water dynamics (northwestern Mediterranean). Mar Ecol Prog Ser 161:255-264

Submitted: April 7, 1998, Accepted: October 20, 1998

Proofs received from author(s): February 4, 1999 